Original Research Paper

\title{
Industri Kreatif Pengolahan Buah Nanas Menjadi Varian Keripik untuk Meningkatkan Perekonomian Masyarakat di Desa Lendang Nangka Utara
}

\author{
Nurlatifa, Ainul Qusyairi ${ }^{1}$, Baiq Usniati ${ }^{1}$, Dina Aulia ${ }^{1}$, Ely Aulia Safitri ${ }^{1}$, Emil Ismaya ${ }^{1}$, Ida Fauziah ${ }^{1}$, Ira \\ Madiana $^{1}$, Irfanul Furqan ${ }^{1}$, Laelatul Fajri ${ }^{1}$, Lalu Muhammad Maqbul Alghifari ${ }^{1}$, Muhammad Zainul \\ Majdi $^{1}$, Nur Gita Suciyati ${ }^{1}$, Riki Azwari ${ }^{1}$, Yusri $^{1}$, Yuliatin $^{1}$, Bagdawansyah Alqadri ${ }^{1 *}$ \\ ${ }^{\text {I} P r o g r a m ~ S t u d i ~ P P K n ~ P I P S, ~ F a k u l t a s ~ K e g u r u a n ~ d a n ~ I l m u ~ P e n d i d i k a n, ~ U n i v e r s i t a s ~ M a t a r a m, ~ M a t a r a m, ~ I n d o n e s i a ~}$
}

https://doi.org/10.29303/jpmpi.v3i2.1210

Sitasi: Nurlatifa., Qusyairi, A., Usniati, B., Aulia, D., Safitri, E. A., Ismaya, E., Fauziah, I., Madina, I., Furqan, I., Fajri, L., Alghifari, L. M. M., Majdi, M. Z., Suciyati, N. G., Azwari, R., Yusri., Yuliatin \& Alqadri, B. (2021). Industri Kreatif Pengolahan Buah Nanas Menjadi Varian Keripik untuk Meningkatkan Perekonomian Masyarakat di Desa Lendang Nangka Utara. Jurnal Pengabdian Magister Pendidikan IPA 4(4)

\section{Article history}

Received: 1 Oktober 2921

Revised: 30 Oktober 2021

Accepted: 30 November 2021

*Corresponding Author:

Bagdawansyah Alqadri,

Program Studi PPKn PIPS,

Fakultas Keguruan dan Ilmu

Pendidikan, Universitas

Mataram, Mataram, Indonesia;

Email:

bagda_alqadri@unram.ac.id

\begin{abstract}
Industri kreatif pengolahan buah nanas menjadi varian keripik merupakan suatu terobosan yang dilakuakan untuk memanfaatkan sumber daya alam berupa nanas yang melimpah di Desa Lendang Nagka Utara, Kecamatan Mabagik, Kabupaten Lombok Timur. Pengolahan buah nanas menjadi varian keripik ini dilakukan untuk memanfaatkan sumber daya alam yang melimpah dan juga sebagai langkah untuk meningkatkan ekomomi masyarakat setempat. Tujuan kegiatan ini adalah untuk memberdayakan masyarakat yang ada di Desa Lendang Nangka Utara menajdi masyarakat yang berdaya saing berbasisi industri kreatif. Adapun tahapan dan metode dari kegiatan ini yaitu sosialisasi program (metode diskusi), pembentukan tim pengolahan (metode kolaboratif dan kooperatif) dan pelatihan (metode diskusi dan praktik). Hasil dari kegiatan berupa meningkatnya keterampilan masyarakat dalam pengolahan buah nanas menjadi varian keripik sehingga dapat berdampak pada peningkatan ekonomi masyarakat.
\end{abstract}

Keywords: Industri Kreatif, Pengolahan Nanas, Varian Keripik .

\section{Pendahuluan}

Desa Lendang Nangka Utara merupakan salah satu desa yang terletak di kecamatan Masbagik, kabupaten Lombok Timur, Nusa Tenggara Barat. Berjarak 45 kilometer dari pusat kota Mataram dan membutuhkan waktu sekitar 1 jam 30 menit perjalanan menggunakan kendaraan pribadi dari Universitas Mataram. Desa Lendang Nangka Utara terdiri dari 15 dusun. Berdasarkan data profil desa Lendang Nangka Utara diperoleh bahwa luas wilayah yaitu $9.000 \mathrm{Ha}$ dengan jumlah penduduk sebanyak 10.532 jiwa dengan laki-laki 5.184 jiwa dan perempuan 5.348 jiwa, mayoritas masyarakat bekerja sebagai petani dan pekerjaan sampingan sebagai buruh dengan pendapatan hanya cukup untuk memenuhi kebutuhan kehidupan seharisehari. (Sumber: RPJMdes 2017- 2023).

Nanas merupakan tanaman yang banyak dibudidayakan di Indonesia mulai dari daerah yang ada di Jawa bahkan sampai ke pelosok negeri, hal ini dikarenakan potensi yang dimiliki oleh buah nanas sangat besar (Hidayat, 2008).Ditegaskan lagi dari data yang dikeluarkan oleh Badan Pusat Statistik (2017) bahwa produksi nanas di Indonesia sebesar 1,79 juta ton pertahun dan menempati posisi keempat produksi komoditas buah-buahan unggulan. Desa Lendang Nangka Utara merupakan salah satu desa yang terkenal dengan sebutan desa nanas.Hal ini disebabkan karena potensi sumber daya alam yang banyak dijumpai di desa ini adalah nanas. Kualitas nanas di Desa Lendang Nangka ini tidak diragukan lagi. Ukuran buah yang besar 
dan manis menjadi keunggulan dari buah nanas itu sendiri. Tanaman buah nanas menjadi komoditas buah yang dikembangkan oleh masyarakat sekitar dengan luas 227 Ha. Potensi yang dimiliki ini tidak dapat dikembangkan dengan optimal mulai dari kurangnya daya produksi oleh petani hal ini dikarenakan masih adanya kendala yang dihadapi. Menurut Lubis (2014), penurunan produksi nanas disebabkan karena ketidakmampuan petani untuk menggunakan teknologi seutuhnya. Selain itu juga dalam pemanfaatannya masyarakat masih mengalami kendala disebabkan karena kurangnya keterampilan yang dimiliki masyarakat setempat yang diakibatkan oleh rendahnya tingkat pendidikan dan juga kurangnya sarana prasaran yang tersedia ditambah lagi belum optimalnya kemitraan dengan berbagai stakeholder untuk meningkatkan daya saing dari buah nanas di pasaran.

Berdasarkan observasi awal yang dilakukan pada tanggal 14 Maret 2021 di Dusun Gawah Malang Desa Lendang Nangka Utara bahwa mayoritas komoditas tanaman yang dikembangkan yaitu buah nanas.Komoditas nanas di desa tersebut menjadi tanaman yang memiliki produktivitas yang tinggi. Menurut keterangan yang diberikan oleh salah satu kader Pemberdayaan Kesejahteraan Keluarga (PKK) yakni ibu Nuraini, ia mengungkapkan mayoritas petani di desa Lendang Nangka Utara adalah petani nanas, namun potensi sumber daya alam yang berupa nanas tersebut belum dimanfaatkan secara optimal oleh masyarakat ditambah lagi dengan keterampilan yang dimiliki masih rendah. Hal tersebut dibuktikan dengan masih banyaknya masyarakat yang menjual buah nanas secara utuh, baik di pinggir jalan sepanjang Desa Lendang Nangka Utara, maupun menjual nanas utuh ke pasar di kabupaten/kota ataupun dijual ke para pengempul yang ada.Tidak adanya pengolahan nanas membuat nilai jual menjadi rendah ditambah lagi dengan buah nanas termasuk buah-buahan yang cepat mengalami pembusukan. Perlunya suatu pengolahan yang inovatif untuk memberikan dampak pada peningkatan nilai jual nanas yang berbasis Industri kreatif sekaligus pemberdayaan terhadap masyarakat sehingga menjadikan masyarakat yang mandiri dan memiliki produk berdaya saing.

Industri kreatif merupakan konsep yang sudah dikembangkan sejak tahun 1990-an. Ia muncul seiring dengan penggunaan ekonomi 3 kreatif. Indutri kreatif memiliki definisi yang berbeda-beda, Menurut Pangestu (2007), industri kreatif didefinisikan sebagai industri yang berasal dari pemanfaatan kreativitas, keterampilan serta bakat individu untuk menciptakan kesejahteraan serta lapangan pekerjaan melalui penciptaan dan pemanfaatan daya kreasi dan daya cipta individu tersebut. Sedangkan, Departement of Culture, Media, and Sport (Herlambang, 2015), mendefinisikan industri kreatif sebagai industri yang memiliki originalitas tersendiri dalam hal kreativitas individual, bakat dan kemampuan, yang mana memiliki potensi ekonomi dan penciptaan lapangan kerja yang dikembangkan oleh sumber daya manusia yang kreatif. Dari kedua definisi tersebut maka hal yang utama dari indutri kreatif yaitu memiliki sumber daya manusia yang kreatif. Dalam pengolan nanas yang ada di Desa Lendang Nangka Utara akan kami coba kolaborasikan pemanfaatan Sumber Daya Manusia yang kreatif dan teknologi terkini untuk menciptakan indutri kreatif dengan tujuan meningkatkan perekonomian masyarakat.

Berangkat dari hal-hal diatas, penulis menawarkan program pengabdian dan pemberdayaan terhadap masyarakat yaitu, Industri Kreatif Pengolahan Buah Nanas Menjadi Varian Keripik untuk Meningkatkan Perekonomian Masyarakat di Desa Lendang Nangka Utara, Kecamatan Masbagik, Kabupaten Lombok Timur.

\section{Metode}

Industri kreatif pengolahan buah nanas menjadi varian keripik untuk meningkatkan perekonomian masyarakat di Desa Lendang Nangka Utara dilaksanakan oleh Tim Program Holistik Pemberdayaan dan Pembinaan Desa (PHP2D) HMPS PPKn FKIP Universitas Mataram. Tim ini terdiri atas seorang ketua, dan empat belas anggota serta satu orang dosen pembimbing. Baik ketua, anggota hingga dosen pembimbing berasal dari prodi PPKn FKIP Unram. HMPS PPKn FKIP Unram merupakan salah satu organisasi himpunan mahasiswa di Universitas Mataram yang berhasil lulus seleksi tingkat nasional dan didanai langsung oleh Kemendikbud RI tahun 2021 dalam program kerja Kampus Merdeka.

\section{Tempat dan Waktu}

Kegiatan ini dilaksanakan di Desa Lendang Nangka Utara, kecamatan Masbagik, kabupaten Lombok Timur, Nusa Tenggara Barat dengan potensi hasil alam utama adalah Nanas. Proses kegiatan dilakukan selama lima bulan, dimulai dari bulan Agustus sampai dengan Desember 2021.

\section{Khalayak Sasaran}

Masyarakat sasaran dalam kegiatan program ini yaitu seluruh masyarakat yang berada di Desa Lendang Nangka Utara yang terdiri dari 15 Dusun yaitu DusunMasjid Bakek, Dusun Benteng Utara, Dusun Loang Sawak I, Dusun Loang Sawak II, Dusun Benteng Selatan I, Dusun Benteng Selatan 
II, Dusun Gawah Malang, Dusun Gonjong Utara, Dusun Montong Sube, Dusun Jimse, Dusun Borok Lelet I, Dusun Borok Lelet II, Dusun Otak Pancor Utara, Dusun Kapitan, dan Dusun Otak Pancor. Dalam pelaksanaannya, tim memilih lima belas orang sebagai perwakilan dari berbagai dusun untuk dilatih cara pengolahan nanas. Orang-orang yang dipilih ini didasarkan atas potensi dan kemauan yang tinggi untuk membangun ekonomi kreatif di Desa Lendang Nangka Utara dan tentunya dengan i'tikad baik dari beberapa masyarakat perwakilan tersebut dapat menjamin keberlangsungan program sampai selesai. Tim membagi lima belas orang ini menjadi empat kelompok pelatihan dalam pengolahan kripik nanas dengan jadwal yang berbeda.

\section{Metode Pengabdian}

Dalam pelaksanaan program PHP2D oleh HMPS PPKn FKIP Unram mememiliki beberapa tahapan, yang mana setiap tahapan memiliki metode antara lain:

\section{a. Sosialisasi}

Metode yang digunakan tim pada saat sosialisasi yakni metode symposium yang mana metode ini berbentuk diskusi dengan menghadirkan pembicara. Metode ini dijalankan seperti aktivitas rapat atau petemuan sosial yang didalamnya terdapat penyampaian informasi kepada masyarakat desa terkait dengan program yang akan dilaksanakan, tujuan kegiatan, manfaat kegiatan, dan produk yang dihasilkan dalam industri kreatif olahan produk unggulan nanas menjadi varian keripik di desa Lendang Nangka Utara.

\section{b. Pembentukan Tim}

Dalam pembentukan tim pelatihan oleh tim PHP2D HMPS PPKn FKIP Unram menggunakan metode Kolaboratif dan Kooperatif. Dengan menggunakan kedua metode ini dapat merangkum masyarakat dari ke lima belas dusun dengan sistem perwakilan dalam industri kreatif pengolahan nanas ini. Setiap kelompok beranggotakan empat orang yang disesuaikan dengan jadwal kerja masingmasing anggota. c. Pelatihan Pembuatan Produk

Kegiatan pelatihan ini diarahkan oleh seorang ahli yang tentunya sudah berpengalaman dan terampil dibidang pengolahan nanas menjadi kripik. Metode yang digunakan yakni penugasan dan praktik secara langsung. Melalui metode ini, pelatih dan tim membantu untuk membimbing dan mencontohkan peserta agar memiliki keterampilan dalam mengolah nanas untuk nilai jual yang lebih tinggi.

d. Pelatihan Manajemen organisasi dan pemasaran Pelatihan ini menggunakan metode simposium dengan menghadirkan narasumber yang berpengalaman dalam bidang manajemen organisasi dan pemasaran. Pada pelatihan ini narasumber memberikan materi selanjutnya peserta melakukan diskusi dengan pemateri terkait dengan apa yang perlu di fahami.

\section{e. Implementasi kegiatan}

Metode yang digunakan yakni metode demonstrasi. Pada tahap ini, setiap kelompok yang sudah di tentukan sebelumnya, ketika melaksanakan pelatihan sudah dapat menghasilkan produk berupa varian kripik nanas yang siap diperjual belikan. Pemilihan metode ini memiliki tujuan untuk melatih komitmen tim pelatihan dalam mengikuti langkah demi langkah dalam proses pengolahan buah nanas.

\section{Indikator Keberhasilan}

Setelah melakukan seluruh tahapan kegiatan, diperlukan indikator untuk menghitung keberhasilan pada setiap tahapan. Rumusan indikator keberhasilan dari kegiatan ini sebagai berikut;

\section{a. Sosialisasi}

Pada sesi akhir kegiatan sosialisasi, peserta menunjukkan pemahaman terkait dengan apa yang telah disampaikan oleh tim PHP2D HMPS PPKn FKIP Unram . Hal ini ditandai dengan antusia dan banyaknya partisipan yang bertanya terkait dengan kelanjutan program ini dan meminta solusi terkait dengan beberapa kendala dalam menyikapi berbagai permasalahn dalam industri kreatif pengolahan nanas menjadi varian kripik sebagai produk unggulan Desa Lendang Nangka Utara. 


\section{b. Pembentukan Tim}

Pada tahap ini, indikator keberhasilnnya dapat dilihat dari terbentuknya tim pelatihan industri kreatif pengolahan nanas menjadi varian kripik dari lima belas orang yang merupakan perwakilan dari setiap dusun di Desa Lendang Nangka Utara.

\section{c. Pelatihan Pembuatan Produk}

Setelah pembagian tim, proses selanjutnya yakni pelatihan. Indikator keberhasilan pada tahap ini dilihat dari terpenuhinya setiap jadwal dari pelatihan oleh kelompok yang sudah dientukan. Selain itu, tim pelatihan menunjukkan peningkatan kemampuan dalm proses pengolahan nanas yang ditandai dengan setelah pelatihan pertama dan kedua, tim pengolahan sudah bisa mengerjakan olahan tersebut tanpa diawasi oleh ahli dan untuk pelatihan ketiga dan keempat sudah dapat menjalankan produksi secara mandiri.

\section{d. Pelatihan Manajemen Organisasi dan Pemasaran}

Indikator keberhasilan pada tahap ini ditunjukkan dengan peningkatan pemahaman masyarakat mengenai cara memanajemen organisasi dan bagaimana melakukan pemasaran yang baik. Hal ini dapat dilihat dari peningkatan pengetahuan masyarakat setelah mengikuti pelatihan dengan indeks kenaikan pengetahuan hingga $75 \%$. Pelatihan manajemen organisasi dan pemasaran ini memberikan kemudahan dalam keberlanjutan tim yang sudah dibentuk dan juga keberlanjutan produk yang sudah di produksi untuk dipasarkan baik secara langsung maupun melalui digital.

\section{e. Implementasi kegiatan}

Pada tahap ini, indikator keberhasilannya dapat merujuk pada indentifikasi tim pelatihan sudah dapat menghasilkan produk berupa varian kripik nanas yang siap diperjual belikan. Kemudian hal lainnya yang dapat dijadikan indikator keberhasilan yaitu komitmen dari tim pelatihan yang selalu konsisten menghadiri pelatihan dari seluruh rangkaian acara dalam industri kreatif pengolahan nanas menjadi berbagai varian kripik.

\section{Hasil dan Pembahasan}

Tim PHP2D HMPS PPKn FKIP Unram membagi kegiatan ini menjadi empat tahapan di Desa Lendang Nangka Utara, kecamatan Masbagik, kabupaten Lombok Timur, Nusa Tenggara Barat Setiap tahapan yang dilaksanakan mengikuti rancangan awal yang sudah ditentukan. Setelah setiap tahapan program dilaksanakan, didapatkan hasil sebagai berikut:

\section{A. Sosialisasi Program}

Lokasi yang dijadikan tempat pemberdayaan adalah Desa Lendang Nangka Utara, Kecamatan Masbagik, Kabupaten Lombok Timur, Nusa Tenggara Barat. Batas wilayahnya terletak pada sebelah utara dan timur berbatasan dengan Desa Jurit Baru, Kecamatan Pringgasela, di sebelah selatan berbatasan dengan Desa Lendang Nangka, Kecamatan Masbagik, dan di sebelah barat berbatasan dengan Desa Kembang Kuning, Kecamatan Sikur. Terdapat lima belas dusun di Desa Lendang Nangka Utara yaitu, Dusun Masjid Bakek, Dusun Benteng Utara, Dusun Lowang Sawak I, Dusun Lowang Sawak II, Dusun Benteng Selatan I, Dusun Benteng Selatan II, Dusun Gawah Malang, Dusun Gonjong Utara, Dusun Montong Sube, Dusun Jimse, Dusun Borok Lelet I, Dusun Borok Lelet II, Dusun Otak Pancor Utara, Dusun Kapitan, dan Dusun Otak Pancor. Survey awal dilaksanakan pada hari Minggu, 14 Maret 2021 yang berlokasi di Desa Lendang Nangka Utara, Kecamatan Masbagik.

Survey awal ini dilakukan melalui metode wawancara dan observasi dengan narasumber dari masyarakat Desa Lendang Nangka Utara. Survey awal ini bertujuan untuk mengetahui kondisi SDA, SDM, dan potensi lain yang ada di desa tersebut.Kondisi sosial Desa Lendang Nangka Utara adalah sebagian besar penduduknya bermata pencaharian sebagai petani karena terdapat banyak persawahan dan perkebunan yang luas yang digunakan dalam berbagai aktivitas pertanian maupun perkebunan. Selain itu, mayoritas masyarakat setempat menjalani profesi yang lain seperti buruh, tukang, pedagang, dan lain-lain. Berdasarkan pekerjaan yang dijalankan oleh masyarakat setempat dapat dikatakan bahwa tingkat kemakmuran ekonomi masyarakatnya masih berada pada tingkat menengah ke bawah secara keseluruhan. Hal ini diperkuat juga dengan 
keterangan yang diperoleh melalui wawancara dengan salah satu anggota kader yang bernama Ibu Nuraini, bahwa masyarakat setempat sebagian besar bekerja sebagai petani sehingga memiliki pendapatan ekonomi pada tingkat menengah ke bawah. Sarana komunikasi pun masih belum maksimal di daerah tersebut, bahkan banyak masyarakat yang masih belum mengerti cara mengakses internet dengan benar.

Sementara itu, kondisi pendidikan masyarakat khususnya remaja Desa Lendang Nangka Utara juga tergolong rendah. Tidak banyak masyarakat yang berpendidikan hingga tingkat perguruan tinggi. Keterbatasan ekonomi untuk menunjang biaya pendidikan menjadi faktor utama penyebab mayoritas masyarakat tidak melanjutkan pendidikan ke jenjang yang lebih tinggi. Selain itu, faktor lainnya adalah kesadaran masyarakat terhadap pendidikan itu masih rendah.Sehingga ratarata pendidikan masyarakat di Desa Lendang Nangka Utara hanya sampai tingkat Sekolah Dasar.

Namun di balik problematika-problematika tersebut, sumber daya alam di Desa Lendang Nangka Utara melimpah, salah satunya adalah buah nanas. Di Desa Lendang Nangka Utara sendiri hanya memiliki satu rumah olahan nanas dan itu pun jarang berjalan dengan lancar disebabkan sumber daya manusianya yang belum mumpuni. Nanas ini dapat diinovasikan menjadi berbagai olahan makanan salah satunya yaitu keripik nanas. Dengan banyaknya dusun di Desa Lendang Nangka Utara dan sumber daya alam terutama nanas yang melimpah bisa dikatakan belum seimbang jika hanya memiliki satu rumah olahan nanas saja. Oleh sebab itu masyarakat biasanya langsung menjual buah nanas hasil panennya ke pengepul untuk nanti dijual ke pasar tanpa diolah terlebih dahulu.

Berdasarkan hasil survei tersebutlah yang menjadi acuan dari tim PHP2D HMPS PPKn FKIP Unram untuk melaksanakan sosialisasi kepada masyarakat Desa Lendang Nangka Utara. Pelaksanaan sosialisasi ini memiliki khalayak sasaran yakni masyarakat dengan perwakilan dari berbagai dusun. Pihak yang terlibat pada sosialisasi ini terdiri atas perangkat desa, masyarakat umum beserta tim PHP2D HMPS PPKn.Sosialisasi awal ini bertujuan untuk memperkenalkan masyarakat Desa Lendang Nangka Utara tentang program PHP2D yang akan dilaksanakan dengan materi yang disampaikan yaitu rencana program kerja selama melakukan pengabdian dan pemberdayaan masyarakat di Desa Lendang Nangka Utara.

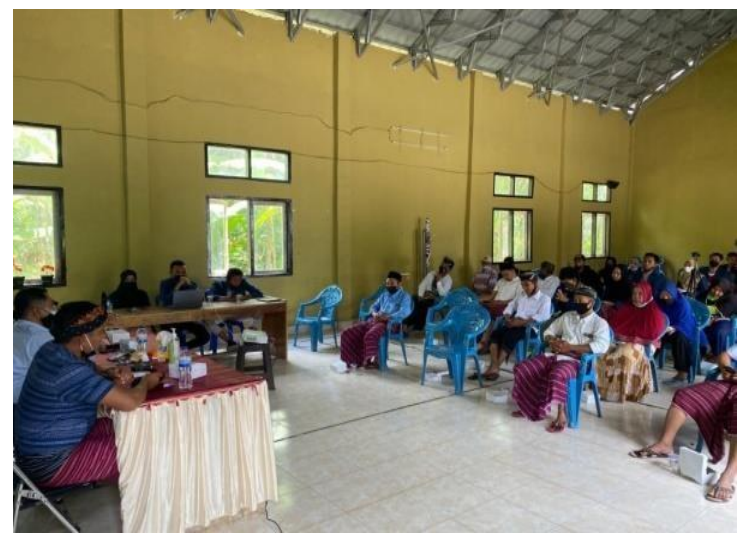

Gambar 1. Sosialisasi Program Holistik dan

Pembinaan Desa bertempat di Aula Kantor Desa

\section{B. Pembentukan Tim}

Setelah sosialisasi program, kegiatan dilanjutkan dengan pembentukan tim. Pembentukan tim ini bertujuan untuk mempermudah dalam menjalankan program dan sebagai masyarakat sasaran yang akan diberdayakan. Pembentukan tim dilakukan oleh mahasiswa Tim PHP2D dengan melibatkan masyarakat setempat sehingga didapatkan lima belas orang yang merupakan perwakilan dari masing-masing dusun yang ada di Desa Lendang Nangka Utara. Dalam pembentukan tim dibuat susunan kepenguruasan yang terdiri dari ketua dan anggota.

Setelah tim dibentuk selanjutnya dilakukan diskusi dengan Tim PHP2D untuk membahas rencana program dan pembagian tugas yang 7 akan dilaksanakan. Adapun pembagian tugasnya sebagai berikut:

1. Pengolahan, pengolahan merupakan tugas yang utama dikarenakan ini akan berkaitan dengan produksi dari varian keripik nanas yang akan dilakukan oleh tim yang sudah dibentuk.

2. Pengemasan, pengemasan merupakan tugas lanjutan dari pengolahan. Pengemasan memiliki peranan yang penting karena berkaitan dengan kualitas produk yang dihasilkan. Dalam pengemasan ini kami melakukan inovasi untuk membuat kemasan semenarik mungkin.

3. Pemasaran, pemasaran merupakan tugas yang ketiga yang akan menjadi satu kesatuan dengan tugas yang lainnya. Pemasaran yang akan dilakukan dengan menerapkan dua elemen yaitu 
secara langsung dan juga memanfaatkan pemasaran digital.

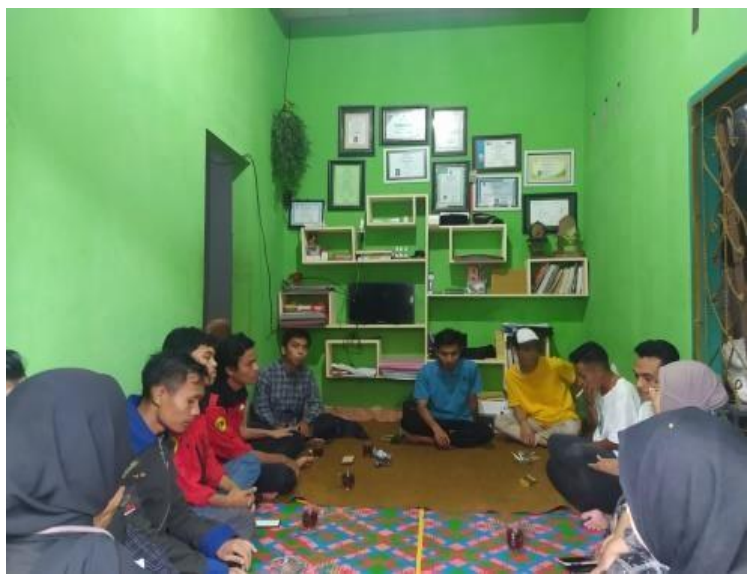

Gambar 2 Pembentukan Tim Pengolahan Nanas.

\section{Pelatihan Pembuatan Produk}

Setelah pembentukan tim, kegiatan selanjutnya yaitu pelatihan yang dilakukan sebanyak empat kali pelatihan produk dan sekaligus pengemasan. Pelatihan Pertama yaitu pelatihan pembuatan produk, dalam pelatihan pertama ini dilakukan demonstrasi pembuatan produk dari awal proses, mulai dari pengupasan nanas sampai dengan penyimpanan nanas yang akan digoreng atau dimasukkan ke mesin vacuum fraying. Dalam pelatihan pertama ini semua anggota tim terlibat aktif dan melaukan pembagian tugaa untuk mempermudah dalam pengolahan. Selanjutnya, padaPelatihan Kedua dilakukan penggorengan nanas dengan menggunakan mesin vacuum fraying.Pengorengannanas untuk menjadi keripik ini dilakukan oleh satu orang dari tim sebagai operator mesin sedangkan yang lainnya menyiapkan segala bahan untuk nantinya digunakan setelah penggorengan.

Pelatihan ketiga, setelah nanas digoreng maka selanjutnya dilakukan pendinginan dan juga penirisan minyak yang ada dalam kripik nanas. Proses pendinginan dan penirisan kripik nanas yang sudah digoreng menggunakan alat spiner. Setelah kripik nanas ditiriskan, selanjutnya dilakukan pemberian varian rasa pada keripik dan pengemasan produk yang sudah selesai proses pemberian rasa. Pengemasan dalam produk dilakukan secara bersama-sama oleh tim pengolahan dengan tim PHP2D. Pengemasan dilakukan dengan menjaga kebersihan dan standar kualitas produk. Pelatihan terakhir yaitu pelatihan keempat, tim yang sudah dibentuk diberikan kebebasan secara mandiri untuk melakukan produksi pembuatan keripik nanas sampai dengan pengemasan hal ini dilakukan untuk mengukur hasil pelatihan yang dilakukan. Dari peltihan keempat hasil yang didapatkan sudah $80 \%$ anggota tim dapat melakukan proses produksi sampai dengan pengemasan sehingga hal ini sebagai indikator keberhasilan yang baik dalam suatu penilaian.

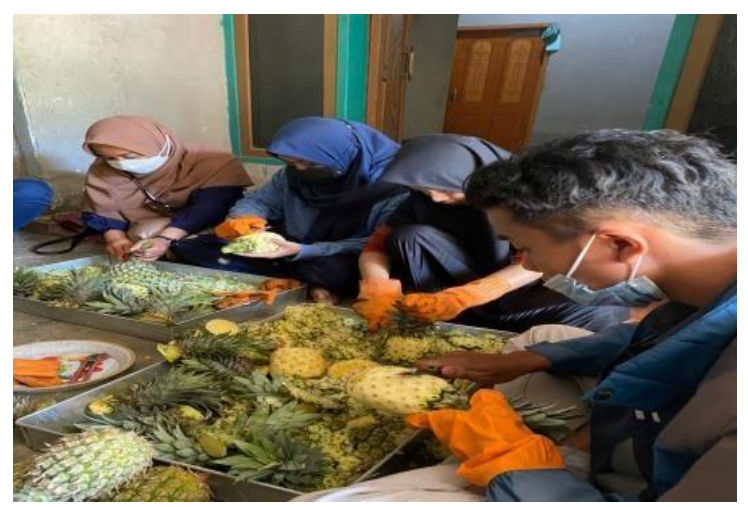

Gambar 3. Pelatihan Pembuatan Keripik Nanas.

Setelah seluruh proses pelatihan dilakukan, tim yang sudah dibentuk dapat melakukan produksi pembuatan varian rasa kripik nanas dan diharapkan dapat melakukan secara 8 mandiri kedepannya untuk keberlanjutan industri kreatif yang sudah dibentuk.

\section{Pelatihan Manajemen Organisasi dan Pemasaran}

Pelatihan Manajemen Organisasi dan Pemsaran merupakan keberlanjutan dari pelatihan produksi yang telah dilakukan.Pelatihan ini merupakan pelatihan dengan dua materi yaitu manajemen organisasi dan pemasaran. Pelatihan manajemen organisasi dilakukan untuk memberikan pengetahuan tentang tata kelola organisasi dalam hal ini tim pengolahan nanas yang telah dibentuk, selanjutnya pelatihan pemasaran dilakukan sebagai langkah tindak lanjut dari produksi kripik nanas yang sudah dilakukan. Pelatihan Manajemen Organisasi dan Pemasaran dilakukan kerja sama dengan dinas perindustrian kabupaten Lombok Timur yang dimana dilakukan di Aula Kantor Desa (10/11/21).

Pelatihan Manajemen Organisasi dan Pemsaran yang dilakukan di Aula kantor desa dihadiri oleh pemateri yaitu sekretaris dinas perindustrian kabupaten Lombok Timur, kepala 
desa Lendang Nangka Utara, dosen pembimbing PHP2D dan juga tim pengolahan nanas. Dalam pelatihan ini dilakukan penyampaian materi tentang menjaga organisasi yang telah dibentuk dengan melakukan komunikasi yang baik antar anggota, selain itu juga dalam penyampaian materi tentang pemasaran didorong untuk meningkatkan keterampilan dalam hal pemasaran berbasis digital untuk memperluas segmen pasar dari produk kripik nanas.

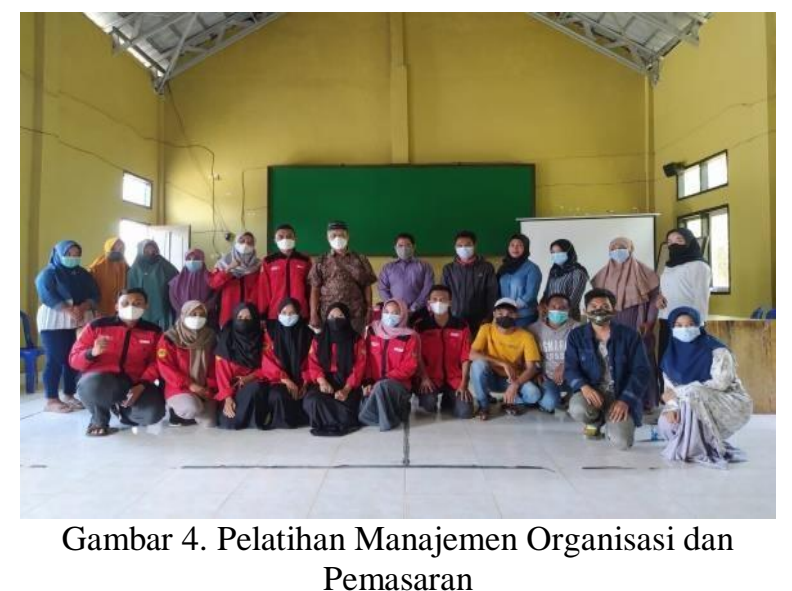

Setelah seluruh proses kegiatan dilakukan, maka diharapkan setelah melakukan pelatihan manajemen organisasi dan pemasaran terbentuknya suatu kemaandirian dalam tim pengolahan nanas kedepannya.

\section{Kesimpulan}

Berdasarkan seluruh data dan uraian yang telah dijabarkan, maka dapat disimpulkan bahwa kegiatan PHP2D telah berhasil dilakukan di Desa Lendang Nangka Utara.Adapun indikator keberhasilan yang sudah dicapai yaitu pertama, adanya perubahan perilaku masyarakat hal tersebut dilakukan dengan meningkatkan keteramnpilan yang dimiliki masyarakat dalam pengolahan nanas. Kedua, adanya perubahan fisik yang dilakukan dengan meningkatnya pendapatan masyarajat dari adanya pengolahan nanas. Ketiga, terjalinnya mitra dengan elemen terkait anatara lain dengan dinas perindustrian kabupaten Lombok Timur. Keempat, perubahan kelembagaan lokal yang sebelumnya berbasis kewilayahan tingkat dusun menjadi kelembagaan yang sudah dapat dikenal secara umum oleh masyarakat yang ada di luar desa. Selanjutnya, untuk menjaga keberlanjutan dari program yang sudah dilakukan diharapkan dilakukan kolaborasi lebih luas dengan berbagai pihak yang terkait

\section{Daftar Pustaka}

Badan Pusat Statistik. 2018. Statistik Tanaman Buahbuahan dan Sayuran Tahunan Indonesia 2017. Badan Pusat Statistik: Jakarta.

Herlambang, Y. (2015). Peran Kreativitas Generasi Muda Dalam Industri Kreatif Terhadap Kemajuan Bangsa. Tematik, 2 (1).

Hidayat, P. (2008). Teknologi Pemanfaatan Serat Daun Nanas Sebagai Alternatif Bahan Baku Tekstil. Teknoin, 13(2).

Lubis, R. R. B., Daryanto, A., Tambunana, M. R. Rachman, H. P. S. (2014). Analisis Efisiensi Teknis Produksi Nanas. Pusat Data dan Sistem Informasi Pertanian Sekretariat Jenderal Agroekonomi. 32(2): 91-106.

Pangestu, M. E. (2007). Studi Industri Kreatif Indonesia 2007. Departemen Perdagangan Republik Indonesia.

RPJMDes.(2017). Rencana Pembangunan Jangka Menengah Desa Lendang Nangka Utara 20172023. Lendang Nangka Utara 